\title{
Prevalence of hyperprolactinemia in infertile cases and its correlation with TSH in a rural set up hospital
}

\author{
Madhuprita Agrawal*, S. Samal, C. Hariharan, Sweta Agrawal
}

Department of Obstetrics and Gynaecology, Acharya Vinoba Bhave Rural Hospital, Wardha, Maharashtra, India

Received: 18 October 2013

Accepted: 27 October 2013

\section{*Correspondence:}

Dr. Madhuprita Agrawal,

E-mail: sweetagr@yahoo.co.in

(C) 2013 Agrawal M et al. This is an open-access article distributed under the terms of the Creative Commons Attribution Non-Commercial License, which permits unrestricted non-commercial use, distribution, and reproduction in any medium, provided the original work is properly cited.

\begin{abstract}
Background: Hyperprolactinemia is a common endocrine disorder of hypothalamic-pituitary ovarian axis affecting the reproductive functions. Despite the significant role of hyperprolactinemia in infertility, serum prolactin estimation is still not universally done as a part of evaluation of infertility. This study intended to find out the incidence of hyperprolactinemia in infertility, highlight the importance of assessment of serum TSH level in hyperprolactinemia.

Methods: 200 cases of primary and secondary infertility were investigated for serum prolactin levels at Acharya Vinoba Bhave Rural Hospital, Wardha from 2011-2013.

Results: There were $130(65 \%)$ cases of primary infertility as against $70(35 \%)$ cases of secondary infertility. A maximum of $106(53 \%)$ cases were in the age group of $26-30$ years, with the mean age as $27.50 \pm 3.76 y e a r s$. There were $11.5 \%$ cases of hyperprolactinemia out of 200 cases of infertility. $21.73 \%$ cases of hyperprolactinemia had hypothyroidism.

Conclusion: The high prevalence of hyperprolactinemia with infertility stresses the fact that all the cases of infertility should be subjected for serum prolactin estimation. Prolactin estimation should be done at early stages of infertility check up rather than straight away going for more costly tests or invasive procedures. There is high crude prevalence of hypothyroidism in hyperprolactinemia. All the cases of hyperprolactinemia should have TSH estimation.
\end{abstract}

Keywords: Hyperprolactinemia, Infertility, Prolactin, Hypothyroidism

\section{INTRODUCTION}

Pregnancy and motherhood are the developmental milestones that are highly emphasized by our culture. When attempts to have a child fails, it can be an emotionally devastating experience for a couple. Infertility is a global health issue, affecting 12 to $14 \%$ of the couples worldwide and remains stable in recent years. ${ }^{1}$ The World Health Organization (WHO) estimates that 60 to 80 million couples worldwide currently suffer from infertility. ${ }^{2}$

According to the standard protocol, infertility evaluation usually identifies different causes, including male infertility (30\%), female infertility $(35 \%)$, the combination of both $(20 \%)$, and finally unexplained or "idiopathic" infertility $(15 \%){ }^{3}$
Hyperprolactinemia is one of the most common endocrine disorder of the hypothalamic-pituitary ovarian axis affecting the reproductive functions. ${ }^{4}$ It is present in as high as 9 to $17 \%$ in women with reproductive disorders. ${ }^{5}$

There is also a higher crude prevalence of hypothyroidism in hyperprolactinemia in infertile women. TRH in addition to increasing TSH causes rise in prolactin level. ${ }^{6}$ Increased level of serum prolactin has been reported in $30 \%$ of patients with primary hypothyroidism. $^{7}$ Hypothyroidism is commonly associated with hyperprolactinemia and such patients exhibit ovulatory failure. Hence, assessment of serum TSH and prolactin levels are mandatory in the work up of all infertile women. ${ }^{8}$ Despite long history of hyperprolactinemia and its role in gonadal dysfunction, its still not been universally done as a part of routine 
evaluation of infertility in rural areas. Therefore this study was intended to find out the prevalence of hyperprolactinemia in rural area and importance of assessment of serum TSH in hyperprolactinemia.

\section{METHODS}

It was a cross-sectional study carried out in the department of Obstetrics and Gynaecology at Acharya Vinoba Bhave Rural Hospital, Sawangi, Wardha, from August 2011 to July 2013. 200 cases of primary and secondary infertility were considered. Cases excluded were Infertility due to isolated male factor, females with any obvious organic lesion or any congenital anomaly of urogenital tract, females who are on drugs affecting prolactin levels.

\section{Methodology}

Firstly, preliminary details and complete history was recorded. Following this cases were thoroughly examined with special attention to secondary sexual character, thyroid enlargement and presence of galactorrhoea and then the cases were investigated. Serum prolactin was estimated in all the 200 cases of infertility. The cases with prolactin levels more than $25 \mathrm{ng} / \mathrm{ml}$ were considered as hyperprolactinemic. Infertile cases with hyperprolactinemia were then subjected for $\mathrm{TSH}$ estimation and then values of TSH correlated with increased prolactin levels. The data obtained, was evaluated by Chi - square test. Probability (p) values $<0.05$, were regarded as statistically significant.

\section{RESULTS}

There were $130(65 \%)$ cases of primary infertility as against $70(35 \%)$ cases of secondary infertility ( $<<0.0001$, Significant). A maximum of 106 (53\%) cases were in the age group of 26-30 years, with the mean age as 27.50 \pm 3.76 years. Mean age of 130 cases of primary infertility was $27.16 \pm 3.76$ years and mean age of 70 cases of secondary infertility was 28.12 \pm 3.71 years (Table 1 ). There were $23(11.5 \%)$ cases of hyperprolactinemia (>25 $\mathrm{ng} / \mathrm{ml}$ ) out of 200 cases of infertility (Table 2 ). The cases of infertility without hyperprolactinemia were $177(88.5 \%)$. Out of 130 cases of primary infertility 16 cases and out of 70 cases of secondary infertility 7 cases had serum prolactin more than $25 \mathrm{ng} / \mathrm{ml}$ (hyperprolactinemia). Serum prolactin was greater than $75 \mathrm{ng} / \mathrm{ml}$ only in 1 case of primary infertility and none in secondary infertility (Table 3 ).

Mean Prolactin in primary and secondary infertility zvalue $=1.07$ and $p$-value $=0.286$, Non-significant ( $>0.05)$. The present study has shown that $65(32.5 \%)$ cases sought medical advice within 5 years of infertility and remaining $135(67.5 \%)$ cases sought medical advice after 5 years. In primary infertility group, 2 cases had duration of infertility greater than 15 years and in secondary infertility group 3 cases had greater than 15 years duration of infertility (Table 4).

Table 1: Distribution of cases according to age and type of infertility.

\begin{tabular}{|c|c|c|c|c|c|c|}
\hline \multirow{2}{*}{$\begin{array}{l}\text { Age in } \\
\text { years }\end{array}$} & \multicolumn{2}{|c|}{$\begin{array}{l}\text { Primary } \\
\text { Infertility }\end{array}$} & \multicolumn{2}{|c|}{$\begin{array}{l}\text { Secondary } \\
\text { Infertility }\end{array}$} & \multicolumn{2}{|c|}{ Total } \\
\hline & No. & $\%$ & No. & $\%$ & No. & $\%$ \\
\hline$\leq \mathbf{2 0}$ & 04 & 2 & 01 & 0.5 & 05 & 2.5 \\
\hline $21-25$ & 43 & 21.5 & 14 & 07 & 57 & 28.5 \\
\hline $26-30$ & 65 & 32.5 & 41 & 20.5 & 106 & 53 \\
\hline 31-35 & 16 & 8 & 11 & 5.5 & 27 & 13.5 \\
\hline$\geq 36$ & 02 & 1 & 03 & 1.5 & 05 & 2.5 \\
\hline Total & 130 & $65 \%$ & 70 & $35 \%$ & 200 & $\begin{array}{l}100 \\
\%\end{array}$ \\
\hline $\begin{array}{l}\text { Mean } \\
\text { Age }\end{array}$ & \multicolumn{2}{|c|}{27.16} & \multicolumn{2}{|c|}{28.12} & \multicolumn{2}{|c|}{27.50} \\
\hline SD & \multicolumn{2}{|l|}{3.76} & \multicolumn{2}{|l|}{3.71} & \multicolumn{2}{|l|}{3.76} \\
\hline
\end{tabular}

Table 2: Distribution of cases according to level of serum prolactin.

\begin{tabular}{|lll|}
\hline $\begin{array}{l}\text { Levels of Serum } \\
\text { Prolactin }(\mathrm{ng} / \mathrm{ml})\end{array}$ & $\begin{array}{l}\text { No. of } \\
\text { cases }\end{array}$ & $\begin{array}{l}\text { Percentage } \\
(\%)\end{array}$ \\
\hline $\mathbf{< 5}$ & 04 & 02 \\
\hline $\mathbf{5 - 2 5}$ & 173 & 86.5 \\
\hline $\mathbf{> 2 5}$ & 23 & 11.5 \\
\hline Total & 200 & 100 \\
\hline
\end{tabular}

Table 3: Levels of serum prolactin in cases with primary and secondary infertility.

\begin{tabular}{|lllllll|}
\hline $\begin{array}{l}\text { Levels of } \\
\text { serum } \\
\text { PRL(ng/ml) }\end{array}$ & \multicolumn{2}{l}{$\begin{array}{l}\text { Primary } \\
\text { infertility }\end{array}$} & \multicolumn{2}{l}{$\begin{array}{l}\text { Secondary } \\
\text { infertility }\end{array}$} & \multicolumn{2}{l|}{ Total } \\
\hline$<5$ & 03 & 1.5 & 01 & 0.5 & 04 & 02 \\
\hline $\mathbf{0 5 - 2 5}$ & 111 & 55.5 & 62 & 31 & 173 & 86.5 \\
\hline $\mathbf{2 5 - 5 0}$ & 13 & 6.5 & 06 & 03 & 19 & 09.5 \\
\hline $\mathbf{5 0}-\mathbf{7 5}$ & 02 & 01 & 01 & 0.5 & 03 & 01.5 \\
\hline $\mathbf{> 7 5}$ & 01 & 0.5 & - & - & 01 & 0.5 \\
\hline Total & 130 & $65 \%$ & 70 & $35 \%$ & 200 & $100 \%$ \\
\hline Mean & 15.26 & 13.71 & 14.72 & \\
\hline SD & 10.31 & 8.64 & & 9.76 & \\
\hline
\end{tabular}


Table 4: Distribution of cases according to duration of infertility.

\begin{tabular}{|llllll|}
\hline \multirow{5}{*}{$\begin{array}{l}\text { Type of } \\
\text { infertility }\end{array}$} & $\begin{array}{l}\text { Duration in years } \\
\text { No. }(\%)\end{array}$ & $\begin{array}{l}\text { No. } \\
(\%)\end{array}$ & No. $(\%)$ & $\begin{array}{l}\text { No. } \\
(\%)\end{array}$ & $\begin{array}{l}\text { No. } \\
(\%)\end{array}$ \\
\cline { 2 - 5 } Primary & $\begin{array}{l}51 \\
(25.5)\end{array}$ & $52(26)$ & $\begin{array}{l}25 \\
(12.5)\end{array}$ & $\begin{array}{l}02 \\
(01)\end{array}$ & $\begin{array}{l}130 \\
(65)\end{array}$ \\
\hline Secondary & $\begin{array}{l}14 \\
(07)\end{array}$ & $28(14)$ & $\begin{array}{l}25 \\
(12.5)\end{array}$ & $\begin{array}{l}03 \\
(1.5)\end{array}$ & $\begin{array}{l}70 \\
(35)\end{array}$ \\
\hline Total & $\begin{array}{l}65 \\
(32.5)\end{array}$ & $80(40)$ & $50(25)$ & $\begin{array}{l}05 \\
(2.5)\end{array}$ & $\begin{array}{l}200 \\
(100)\end{array}$ \\
\hline
\end{tabular}

There were 23 cases of hyperprolactinemia, of these the maximum of $19(82.6 \%)$ cases had duration of infertility of less than 10 years and only 4 cases had more than 10 years of infertility (Table 5). A majority of 19 (82.6\%) hyperprolactinemic cases, had duration of infertility less than 10 years, of which a maximum of $15(65.21 \%)$ cases had serum prolactin value below $45 \mathrm{ng} / \mathrm{ml}$. Four cases of infertility with serum prolactin value $>45 \mathrm{ng} / \mathrm{ml}$ had presented in 5-10 years of infertility (Table 6). 5 cases out of 23 hyperprolactinemic cases had hypothyroidism (Table 7).

Table 5: Duration and type of infertility in hyperprolactinemic group.

\begin{tabular}{|llllll|}
\hline \multicolumn{5}{c}{ Duration in years } \\
$\begin{array}{l}\text { Type of } \\
\text { infertility }\end{array}$ & $<5$ & $5-10$ & $10-15$ & $\geq 15$ & Total \\
& No. $(\%)$ & No. $(\%)$ & $\begin{array}{l}\text { No. } \\
(\%)\end{array}$ & $\begin{array}{l}\text { No. } \\
(\%)\end{array}$ & $\begin{array}{l}\text { No. } \\
(\%)\end{array}$ \\
\hline Primary & 07 & 07 & 02 & & 16 \\
& $(30.43)$ & $(30.43)$ & $(8.69)$ & - & $(69.56)$ \\
\hline Secondary & 01 & 04 & 02 & - & 07 \\
& $(04.34)$ & $(17.39)$ & $(8.69)$ & & $(30.43)$ \\
\hline Total & 08 & 11 & 04 & - & 23 \\
& $(34.78)$ & $(47.82)$ & $(17.39)$ & & $(100)$ \\
\hline
\end{tabular}

Table 6: Levels of serum prolactin and duration of infertility in hyperprolactinemic group

\begin{tabular}{|llllll|}
\hline \multirow{5}{*}{$\begin{array}{l}\text { Levels of } \\
\text { Serum } \\
\text { PRL(ng/ml) }\end{array}$} & $<5$ & $5-10$ & $10-15$ & $\begin{array}{l}\geq \\
15\end{array}$ & Total \\
& No. (\%) & No. $(\%)$ & No. $(\%)$ & $\begin{array}{l}\text { No. } \\
(\%)\end{array}$ & $\begin{array}{l}\text { No. } \\
(\%)\end{array}$ \\
\hline $\mathbf{2 5 - 3 5}$ & 05 & 04 & 02 & & 11 \\
& $(21.73)$ & $(17.39)$ & $(08.69)$ & - & $(47.82)$ \\
\hline $\mathbf{3 5 - 4 5}$ & 03 & 03 & 02 & - & 08 \\
& $(13.04)$ & $(13.04)$ & $(08.69)$ & & $(34.78)$ \\
\hline $\mathbf{4 5}$ & - & $\begin{array}{l}04 \\
(17.39)\end{array}$ & - & - & $\begin{array}{l}04 \\
(17.39)\end{array}$ \\
\hline Total & $08(34.78)$ & $11(47.82)$ & $04(17.39)$ & - & $23(100)$ \\
\hline
\end{tabular}

Table 7: Correlation of hyperprolactinemia with TSH.

\begin{tabular}{|ll|}
\hline $\begin{array}{l}\text { Total Hyperprolactinemic } \\
\text { Cases }(\%)\end{array}$ & $\begin{array}{l}\text { No. of Cases With } \\
\text { Hypothyroidism(\%) }\end{array}$ \\
\hline $\mathbf{2 3}(\mathbf{1 0 0})$ & $5(21.73)$ \\
\hline
\end{tabular}

\section{DISCUSSION}

The present study showed that there were $130(65 \%)$ cases of primary infertility as against $70(35 \%)$ cases of secondary infertility. The prevalence of primary and secondary infertility was similar to the study of Ikechebelu JI et al(2003), ${ }^{9}$ Avasthi Kumkum et al(2006) ${ }^{10}$ and Sharma $\mathrm{N}$ et al (2012). ${ }^{11}$ There is overall higher incidence of primary infertility in the population. ${ }^{12}$ In the present study, analysis of age revealed that the maximum of $53 \%$ cases were in the age group of 26 to 30 years with mean age being $27.50 \pm 3.76$. The mean age in primary infertility group was slightly lower 27.16 than the mean age in secondary infertility group 28.12 (Table 1). Similar to the findings of Singh et al(1981), ${ }^{13}$ Ban Mousa Rashid et al (2013). ${ }^{14}$ The higher incidence in the age group of 26-30 years could be related to the decline in the frequency of intercourse with age (Cheung AP et al 2011). ${ }^{15}$

In the present study, serum prolactin value was raised in $11.5 \%$ of the cases of infertility (Table 2) similar to Indu Verma et al (2012), ${ }^{16}$ Thirunavakkarasu K et al $(2013)^{17}$ and less than that of Olooto et al (2012) ${ }^{18}$ and Pratibha et al(1994). ${ }^{19}$ As hyperprolactinemia may result from stress, N. Sonino et al (2004), ${ }^{20}$ and the variable incidence may be due to the different stress levels of infertile women in different areas.

The present study has shown that amongst the hyperprolactinemic cases maximum cases had serum prolactin values between $25-75 \mathrm{ng} / \mathrm{ml}$. Only 1 case had serum prolactin value more than $75 \mathrm{ng} / \mathrm{ml}$ (Table 3 ). Pituitary adenoma is usually seen in cases with serum prolactin value more than $100 \mathrm{ng} / \mathrm{ml}$ was reported by Verhelst J,(2003) ${ }^{21}$ and Schlechte JA(2007). ${ }^{22}$ Thus it is assumed that as the serum prolactin value in the study was less than $100 \mathrm{ng} / \mathrm{ml}$, therefore the possibility of presence of adenoma was less. Mean serum prolactin in primary and secondary infertility group did not show any significant difference similar to finding of N. Sharma et al (2012). ${ }^{11}$

The present study has shown that 65 (32.5\%) cases sought medical advice within 5 years of infertility and remaining $135(67.5 \%)$ cases sought medical advice after 5 years (Table 4). Similarly analysis of duration of infertility in hyperprolactinemic cases has shown that the majority of $19(82.6 \%)$ cases had infertility of less than 10 years (Table 5). These infertility cases also had multiple associated problems like menstrual problems, galactorrhoea etc which affects the psychology of these patients and encourages them to take medical advice early. 4 cases in hyperprolactinemic group had more than 
10 years of infertility. This delay in the treatment could be due to the fact that these cases had marginal elevation of the prolactin levels and were not having any additional symptoms except infertility. So they waited for a longer period.

A majority of 19 (82.6\%) hyperprolactinemic cases, had duration of infertility less than 10 years, of which a maximum of $15(65.21 \%)$ cases had serum prolactin value below $45 \mathrm{ng} / \mathrm{ml}$. 4 cases with serum prolactin value $>45$ $\mathrm{ng} / \mathrm{ml}$ mostly presented within 5-6 years. Only 1 case which had serum prolactin value more than $75 \mathrm{ng} / \mathrm{ml}$ had less than 5 years of duration of infertility (Table 6). It was observed that the higher the prolactin level, the lower the duration of infertility. Topalski-Fistes $\mathrm{N}$ et al $(1999)^{23}$ had commented that as the serum prolactin levels increase, the patient's symptoms may become progressively severe and multiple. As the serum prolactin values increase so do the patient's problems and cases with higher prolactin values come early to the hospital for the treatment.

Out of 23 cases of hyperprolactinemia 5 cases had hypothyroidism. There was no case with hyperthyroidism. There was a positive correlation between hyperprolactinemia and hypothyroidism as reported by Sharma N (2012), ${ }^{11}$ Emokpae MA et al (2011). ${ }^{24}$ The ratio of proportions between hypothyroidism and hyperprolactinaemia was 1:7. Similar finding was reported by Binita Goswami et al $(2009)^{8}$, Avasthi Kumkum et al $(2006)^{10}$ stated a positive correlation of 1:4 was found between hypothyroidism and hyperprolactinemia.

\section{CONCLUSION}

Problems in infertility are challenging and taxing to the clinician which can be solved just by tackling some simple endocrinological condition like hyperprolactinemia.

Hyperprolactinemia is a common finding in an infertile population. Presence of hyperprolactinemia should be looked for in patients presenting with decreased gonadal function .There is a positive correlation in between increased prolactin level and hypothyroidism. Based on these observations it can be said that all patients of infertility need serum prolactin estimation. And serum TSH should be estimated in cases with raised prolactin to find out cases primary hypothyroidism which is to be managed differently.

\section{Funding: None}

Conflict of interest: None declared

Ethical approval: The study was approved by the Institutional Ethical Committee

\section{REFERENCES}

1. Poppe K, Velkeniers B. Thyroid and infertility. Verh K Acad Geneeskd Belg. 2002;64(6):389-99.
2. World Health Organization. Infecundity, infertility, and childlessness in developing countries. DHS Comparative Reports No 9. Calverton, Maryland, USA: ORC Macro and the World Health Organization; 2004.

3. N. Akhter \& S.A. Hassan: Sub-clinical hypothyroidism and hyperprolactinemia in infertile women: Bangaladesh perspective after universal salt iodination. The Internet Journal of Endocrinology. 2009;5.DOI 10.5580/8a.

4. Prabhakar VK, Davis JR. Hyperprolactinemia. Best Pract Res Clin Obstet Gynaecol.2008 Apr;22(2): 341-53.

5. Biller BM, Luciano A. et al. Guidelines for the diagnosis and treatment of hyperprolactinemia. J Rep Med. 1999; 44(suppl):12.

6. Hollowell JG, Staehling NW, Flanders WD, et al. Serum TSH, T(4), and thyroid antibodies in the United States population (1988 to 1994): National Health and Nutrition Examination Survey (NHANES III). J Clin Endocrinol Metab 2002; 87: 489-99

7. Cooper DS, Halpern R, Wood LC, Levin AA, Ridgway EC.L-Thyroxine therapy in subclinical hypothyroidism. A double-blind, placebo-controlled trial. Ann Intern Med 1984; 101:18-24.

8. Goswami B, Patel S, Chatterjee M , Koner BC, Saxena A. Correlation of Prolactin and Thyroid Hormone Concentration with Menstrual Patterns in Infertile Women. J Reprod Infertil. 2009;10(3):207212.

9. Ikechebelu JI, Adinma JI,Orie EF, Ikegwuonu SOJ Obstet Gynaecol. High prevalence of male infertility in southeastern Nigeria. J Obstet Gynaecol.2003 Nov;23(6):657-9.

10. Avasthi Kumkum, Kaur Jasmine , Gupta Shweta et al. Hyperprolactinema and its correlation with hypothyroidism in infertile women. $\mathbf{J}$ Obstet Gynecol India. 2006 ;56: 68-71.

11. Sharma N, Baliarsingh S, Kaushik GG. Biochemical association of hyperprolactinemia with hypothyroidism in infertile women. Clin Lab. 2012; 58(7-8):805-10.

12. Inhorn MC. Global infertility and the globalization of new reproductive technologies: illustrations from Egypt. Soc Sci Med 2003; 56 : 1837-51.

13. Singh VK and Vishnol K. A study of uterine and serum prolactin in cases of female infertility of unknown aetiology. J Obstet Gynecol India. 1981; 31: 788 - 793.

14. Ban Mousa Rashid, Tayfoor Jalil Mahmoud et al . Hormonal Study of Primary Infertile Women. Journal of Zankoy Sulaimani- Part A (JZS-A). 2013;15 (2):137-142

15. Cheung AP et al. Advance reproductive age and fertility. J Obstet Gynaecol Can. 2011;33(11):116575.

16. Verma I, Sood R, Juneja S, Kaur S. Prevalence of hypothyroidism in infertile women and evaluation of response of treatment for hypothyroidism on infertility. Int J App Basic Med Res .2012;2:17-9. 
17. Thirunavakkarasu K, Dutta $\mathrm{P}$, et al. Macroprolactinemia in hyperprolactinemic infertile women. Endocrine. 2013 Mar 30.

18. Olooto, Wasiu Eniola; Adeleye et al. Pattern of Reproductive Hormones (Follicle Stimulating Hormone, Luteinizing Hormone, Estradiol, Progesterone, and Prolactin) Levels in Infertile Women in Sagamu South Western Nigeria. Der Pharmacia Lettre. 2012;4(2):549-553.

19. Pratibha D, Govardhani M, Krihna PT. Prolactin levels in infertility and Bromocriptine therapy in hyperprolactinemia. J Indian Med Assoc 1994; 92(12):397-399.

20. N Sonino, C Navarrini, et al. Life events in the pathogenesis of hyperprolactinemia. European journal of Endocrinology. 2004;151: 61-65.
21. Verhelst J, Abs R. Hyperprolactinemia: pathophysiology and management. Treat Endocrinol. 2003;2(1):23-32.

22. Schlechte JA. Long-term management of prolactinomas. J Clin Endocrinol Metab. Aug 2007;92(8):2861-5.

23. Topalski-Fistes N, Bujas M, et al. Hyperprolactinemia and disorders of the menstrual cycle. Med Pregl. 1999 Mar-May;52(3-5):156-61.

24. Emokpae MA, Osadolor HB, Omole Ohonsi A. Sub-clinical hypothyroidism in infertile Nigerian women with hyperprolactinaemia. Niger J Physiol Sci. 2011 Nov 23;26(1):35-8.

DOI: $10.5455 / 2320-1770 . i j r \operatorname{cog} 20131227$

Cite this article as: Agrawal M, Samal S,

Hariharan C, Agrawal S. Prevalence of hyperprolactinemia in infertile cases and its correlation with TSH in a rural set up hospital. Int J Reprod Contracept Obstet Gynecol 2013;2:626-30. 